\title{
The effects of forest-savanna-grassland gradients on bird communities of Chiquitano Dry Forests domain, in western Brazil
}

\author{
MAURICIO N. GODOI ${ }^{1}$ and EDIVALDO O. DE SOUZA ${ }^{2}$ \\ ${ }^{1}$ Programa de Pós-Graduação em Ecologia e Conservação, Centro de Ciências Biológicas e da Saúde, Universidade \\ Federal de Mato Grosso do Sul, Cidade Universitária, s/n, 79070-900 Campo Grande, MS, Brasil \\ ${ }^{2}$ Departamento de Biologia, Universidade Federal de Mato Grosso do Sul/UFMS, Campus Universitário de Aquidauana, \\ CPAQ, Avenida Oscar Trindade de Barros, 740, Unidade II, Serraria, 79200-000 Aquidauana, MS, Brasil
}

Manuscript received on August 27, 2015; accepted for publication on December 7, 2015

\begin{abstract}
Different vegetation types are distributed in mountains according to altitude, topography and soil. The composition and structure of bird communities in these areas can change in relation to the vegetation gradient, with particular communities occupying each habitat type. In this study we present the changes in composition, species richness and bird abundance over the gradient of forests, savannas and altitudinal grasslands of Maciço do Urucum, a mountainous region located in the Chiquitano Dry Forests domain in western Brazil. We recorded 165 bird species through qualitative and quantitative methods. Forested savannas, riparian forests and submontane forests presented the highest richness and abundance of birds, while arboreal savannas and altitudinal grasslands had intermediate and low values, respectively. The bird composition was similar between riparian and submontane forests, while other vegetation types present more dissimilar bird communities. Our results show differences in composition, richness and bird abundance among the vegetation types present at Maciço do Urucum, and highlight an important function of vegetation gradients for the conservation of bird communities in mountains. Additionally, this is the first study of the bird communities in the Brazilian Chiquitano Dry Forests, an important domain in the west of Brazil which has been poorly studied.
\end{abstract}

Key words: altitudinal grasslands, avian communities, Chiquitano Dry Forests, habitat diversity, habitat use, mountains.

\section{INTRODUCTION}

In landscapes formed by vegetation gradients, bird community composition can be affected by the presence and distribution of different vegetation types (Skowno and Bond 2003, Jankowski et al. 2012). This pattern is due to the fact that many bird species are exclusive to certain habitats or are

Correspondence to: Mauricio Neves Godoi

E-mail: mauricioecologia@hotmail.com abundant in specific vegetation types, while other species have wide distributions with in gradients. Therefore, in areas with vegetation gradients it is possible to distinguish different bird communities associated with each vegetation type (Tubelis and Cavalcanti 2001, Piratelli and Blake 2006, Posso et al. 2013, Godoi et al. 2016).

In mountain habitats, vegetation types are usually distributed in relation to altitude, 
topography and soil (Navarro 1992, Blake and Loiselle 2000). In these regions, the diversity and composition of bird communities could present spatial variations in relation to the presence and distribution of different vegetation types (Navarro 1992, Blake and Loiselle 2000, Melo-Júnior et al. 2001, Mallet-Rodrigues et al. 2010).

In western Brazil there are mountains which present extensive gradients of natural vegetation formed by forests, savannas and natural grasslands, such as the Serra da Bodoquena, Serra de Maracaju and Maciço do Urucum. In the Serra da Bodoquena and Serra de Maracaju inventories of bird species showed high species richness, which could be partially explained by habitat diversity in these regions (Pivatto et al. 2006, Nunes et al. 2013).

In the Maciço do Urucum there is a marked gradient of forests, savannas and altitudinal grasslands (Cáceres et al. 2011), but no basic studies on bird communities exist, with no data on bird species distributions among the different vegetation types. However, these data are essential in understanding how vegetation gradients affect the local composition and structure of bird communities and to bird conservation in Maciço do Urucum.

Furthermore, the Maciço do Urucum is located in the Chiquitano Dry Forests domain, which occurs in eastern Bolivia and in a very restricted area in western Brazil (Vasconcelos and Hoffmann 2006). Although some studies on bird communities have been conducted in the Chiquitano Forests of Bolivia (Davies 1993, Parker 1993, Remsen and Parker 1993, Flores et al. 2001, 2002, Brooks et al. 2005), there are no studies focusing on bird communities in the brazilian Chiquitano Forests.

This study is the first to describe the composition, richness and abundance of bird communities along vegetation gradients in Chiquitano Dry Forests of Brazil. Specifically, the objectives of this study were to: (1) present the species richness, abundances and composition of birds in a vegetation gradient in the Maciço do Urucum and (2) describe the dissimilarities in bird composition between different vegetation types which occur in the landscape of Maciço do Urucum.

\section{MATERIALS AND METHODS}

STUdy AREA

The Maciço do Urucum is a mountainous region located in the Chiquitano Dry Forests domain in the extreme west of Brazil (Olson et al. 2001), near the border of Bolivia, in the county of Corumbá, Mato Grosso do Sul state (Figure 1). This region occupies an area of $1300 \mathrm{~km}^{2}$ with mountains delimited by the Paraguai river to the north and flooded areas of Pantanal to the south and east. The climate of the region is Awa, according Koeppen's classification, with distinct periods of rainy (October-March) and dry (April to September) seasons, with average annual rainfall of $1070 \mathrm{~mm}$ (Pott et al. 2000, Tomas et al. 2010).

The elevation of the mountains varies from 150 to $1130 \mathrm{~m}$ above sea level, and the natural vegetation gradient is formed by decidual and semidecidual seasonal forests, riparian forests, forested savannas (cerradão), arboreal savannas (cerrado stricto sensu) and altitudinal grasslands (campos de altitude) (Pott et al. 2000, Tomas et al. 2010). The plant communities are diverse and suffer biogeographic influences from different domains, like the Chiquitano Forests, Cerrado, Chaco, Atlantic Forests and Amazonian Forests (Pott et al. 2000, 2011, Salis et al. 2004). This region also contains anthropogenic landscapes, like pastures for cattle ranching and areas used for mining of iron, aluminum and limestone, which are the main economic activities in the region.

\section{Methods}

We sample bird communities in 40 stations, using eight stations from each of the following vegetation 


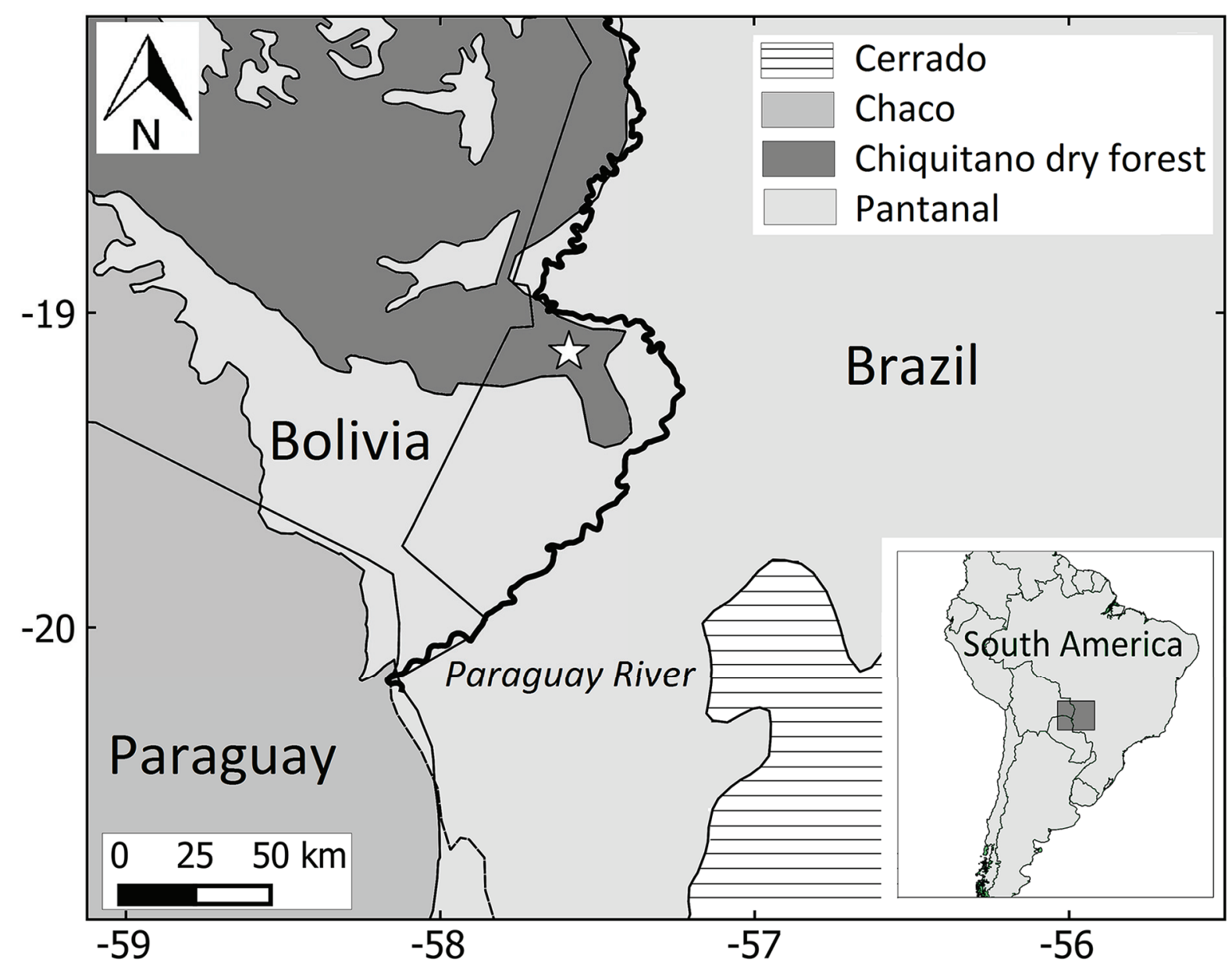

Figure 1 - The Maciço do Urucum (star) in western Brazil, and ecoregion according to Olson et al. (2001).

types: riparian forests, seasonal submontane forests, forested savannas (cerradão), arboreal savannas (cerrado stricto sensu) and altitudinal grasslands (campos de altitude) (Table I).

At each station we placed a point count with a fixed radius of $50 \mathrm{~m}$ and $200 \mathrm{~m}$ of minimal distance from any other point, except for the points located in altitudinal grasslands, where we separated points by $150 \mathrm{~m}$ due to the restricted available area. Each point count was sampled for 10 minutes consecutively, in which the number and species of all birds were recorded through visual or auditory observations (Anjos et al. 2010, Vielliard et al. 2010).

Samplings were always performed in the early morning, between 06:00 and 09:00 hours, when most bird species were active. At each station we sampled eight times ( 80 minutes of sampling effort) between July 2012 and October 2014, except for four stations in the altitudinal grasslands, which we sampled only twice (20 minutes of sampling effort), in July and October 2012 (Table I). In order to more precisely characterize the bird community composition we also recorded bird species that we observed in the intervals between each point count.

Data ANALYsis

For each station we recorded composition, richness and abundance (number of contacts) per species. The species abundance was expressed by Punctual Abundance Index (PAI), which is a ratio between the total number of specie's contacts by total 
TABLE I

Stations used for sampling bird communities along the vegetation gradient in Maciço do Urucum, western Brazil.

\begin{tabular}{|c|c|c|}
\hline Stations & Vegetation Types & Coordinates (Elevation) \\
\hline RF1 & Riparian Forests & 19¹1'54.79”S; 57³8’11.19”W (185 m) \\
\hline RF2 & Riparian Forests & 19¹1'54.19”S; 57³8’4.30”W (192 m) \\
\hline RF3 & Riparian Forests & $19^{\circ} 11^{\prime} 48.65^{\prime} \mathrm{S} ; 57^{\circ} 37^{\prime} 58.62^{\prime \prime} \mathrm{W}(204 \mathrm{~m})$ \\
\hline RF4 & Riparian Forests & $19^{\circ} 11^{\prime} 45.02 ” S ; 57^{\circ} 37^{\prime} 51.87^{\prime \prime} \mathrm{W}(215 \mathrm{~m})$ \\
\hline RF5 & Riparian Forests & 19¹2’52.18”S; 57³6’38.46”W (338 m) \\
\hline RF6 & Riparian Forests & 19॰12'55.57’'S; 57³6’46.20”W (315 m) \\
\hline RF7 & Riparian Forests & $19^{\circ} 12^{\prime} 55.57^{\prime} \mathrm{S} ; 57^{\circ} 36^{\prime} 54.57^{\prime \prime} \mathrm{W}(291 \mathrm{~m})$ \\
\hline RF8 & Riparian Forests & 19¹2’55.17’'S; 57³7’1.43”W (273 m) \\
\hline SF1 & Submontane Forests & $19^{\circ} 12^{\prime} 35.58^{\prime \prime} \mathrm{S} ; 57^{\circ} 36^{\prime} 31.33^{\prime \prime} \mathrm{W}(454 \mathrm{~m})$ \\
\hline SF2 & Submontane Forests & $19^{\circ} 12^{\prime} 40.35^{\prime \prime} \mathrm{S} ; 57^{\circ} 36^{\prime} 34.23^{\prime \prime} \mathrm{W}$ (422 m) \\
\hline SF3 & Submontane Forests & $19^{\circ} 12^{\prime} 44.20^{\prime \prime} \mathrm{S} ; 57^{\circ} 36^{\prime} 35.90^{\prime \prime} \mathrm{W}(381 \mathrm{~m})$ \\
\hline SF4 & Submontane Forests & $19^{\circ} 12^{\prime} 48.52^{\prime \prime} \mathrm{S} ; 57^{\circ} 36^{\prime} 35.20^{\prime \prime} \mathrm{W}(358 \mathrm{~m})$ \\
\hline SF5 & Submontane Forests & 19¹2’22.38”S; 57³0’24.04”W (424 m) \\
\hline SF6 & Submontane Forests & 19॰12’19.41”S; 57³0’21.83”W (472 m) \\
\hline SF7 & Submontane Forests & $19^{\circ} 12^{\prime} 20.21^{\prime \prime} \mathrm{S} ; 57^{\circ} 30^{\prime} 18.85^{\prime \prime} \mathrm{W}(458 \mathrm{~m})$ \\
\hline SF8 & Submontane Forests & $19^{\circ} 12^{\prime} 22.47^{\prime} \mathrm{S} ; 57^{\circ} 30^{\prime} 20.67^{\prime \prime} \mathrm{W}(446 \mathrm{~m})$ \\
\hline FS1 & Forested Savannas (Cerradão) & $19^{\circ} 11^{\prime} 43.33^{\prime \prime} \mathrm{S} ; 57^{\circ} 37^{\prime} 45.21^{\prime \prime} \mathrm{W}(227 \mathrm{~m})$ \\
\hline FS2 & Forested Savannas (Cerradão) & $19^{\circ} 11^{\prime} 41.41^{\prime \prime} \mathrm{S} ; 57^{\circ} 37^{\prime} 38.34^{\prime \prime} \mathrm{W}(238 \mathrm{~m})$ \\
\hline FS3 & Forested Savannas (Cerradão) & $19^{\circ} 11^{\prime} 47.37^{\prime \prime} \mathrm{S} ; 57^{\circ} 37^{\prime} 38.29^{\prime \prime} \mathrm{W}(272 \mathrm{~m})$ \\
\hline FS4 & Forested Savannas (Cerradão) & $19^{\circ} 11^{\prime} 47.04^{\prime \prime} \mathrm{S} ; 57^{\circ} 37^{\prime} 32.50^{\prime \prime} \mathrm{W}(317 \mathrm{~m})$ \\
\hline FS5 & Forested Savannas (Cerradão) & 19॰12’11.78”S; 57³0'13.44”W (522 m) \\
\hline FS6 & Forested Savannas (Cerradão) & $19^{\circ} 12^{\prime} 14.92^{\prime \prime} \mathrm{S} ; 57^{\circ} 30^{\prime} 7.37^{\prime \prime} \mathrm{W}(525 \mathrm{~m})$ \\
\hline FS7 & Forested Savannas (Cerradão) & 19¹2’17.18”S; 57³0’0.60”W (512 m) \\
\hline FS8 & Forested Savannas (Cerradão) & $19^{\circ} 12^{\prime} 14.03 ” \mathrm{~S} ; 57^{\circ} 29^{\prime} 53.48^{\prime \prime} \mathrm{W}(510 \mathrm{~m})$ \\
\hline AS1 & Arboreal Savannas (Cerrado) & $19^{\circ} 12^{\prime} 4.68^{\prime \prime} \mathrm{S} ; 57^{\circ} 36^{\prime} 21.77^{\prime \prime} \mathrm{W}$ (744 m) \\
\hline AS2 & Arboreal Savannas (Cerrado) & 19॰12’2.17’S; 57³6’17.54”W (720 m) \\
\hline AS3 & Arboreal Savannas (Cerrado) & $19^{\circ} 11^{\prime} 58.08^{\prime \prime} \mathrm{S} ; 57^{\circ} 36^{\prime} 11.57^{\prime \prime} \mathrm{W}$ (739 m) \\
\hline AS4 & Arboreal Savannas (Cerrado) & $19^{\circ} 11 ' 52.14^{\prime \prime S} ; 57^{\circ} 36^{\prime} 8.03$ ”W (765 m) \\
\hline AS5 & Disturbed Arboreal Savannas (Cerrado) & 19॰12’5.33”S; 57³0’10.41”W (564 m) \\
\hline AS6 & Disturbed Arboreal Savannas (Cerrado) & 19¹1'57.90”S; 57³0’9.12”W (541 m) \\
\hline AS7 & Disturbed Arboreal Savannas (Cerrado) & $19^{\circ} 11^{\prime} 52.20^{\prime \prime} \mathrm{S} ; 57^{\circ} 30^{\prime} 8.98^{\prime \prime} \mathrm{W}(587 \mathrm{~m})$ \\
\hline AS8 & Disturbed Arboreal Savannas (Cerrado) & $19^{\circ} 11^{\prime} 45.51^{\prime \prime} \mathrm{S} ; 57^{\circ} 30^{\prime} 10.65^{\prime \prime} \mathrm{W}(595 \mathrm{~m})$ \\
\hline AG1 & Altitudinal Grasslands & $19^{\circ} 15^{\prime} 46.05^{\prime \prime} \mathrm{S} ; 57^{\circ} 36^{\prime} 40.69^{\prime \prime} \mathrm{W}(626 \mathrm{~m})$ \\
\hline AG2 & Altitudinal Grasslands & $19^{\circ} 15^{\prime} 51.63 ” \mathrm{~S} ; 57^{\circ} 36^{\prime} 44.74^{\prime \prime} \mathrm{W}(692 \mathrm{~m})$ \\
\hline AG3 & Altitudinal Grasslands & $19^{\circ} 15^{\prime} 52.99^{\prime \prime} \mathrm{S} ; 57^{\circ} 36^{\prime} 51.06^{\prime \prime} \mathrm{W}(639 \mathrm{~m})$ \\
\hline AG4 & Altitudinal Grasslands & $19^{\circ} 15^{\prime} 55.08^{\prime \prime} \mathrm{S} ; 57^{\circ} 36^{\prime} 56.35^{\prime \prime} \mathrm{W}(662 \mathrm{~m})$ \\
\hline AG5 & Disturbed Altitudinal Grasslands & 19¹2’2.77’S; 57³6’33.08”W (910 m) \\
\hline AG6 & Disturbed Altitudinal Grasslands & $19^{\circ} 11^{\prime} 58.41^{\prime \prime} \mathrm{S} ; 57^{\circ} 36^{\prime} 17.28^{\prime \prime} \mathrm{W}(839 \mathrm{~m})$ \\
\hline AG7 & Disturbed Altitudinal Grasslands & 19¹2’1.74”S; 57³6’22.42”W (830 m) \\
\hline AG8 & Disturbed Altitudinal Grasslands & $19^{\circ} 12^{\prime} 7.43^{\prime \prime} \mathrm{S} ; 57^{\circ} 36^{\prime} 23.83^{\prime \prime} \mathrm{W}(745 \mathrm{~m})$ \\
\hline
\end{tabular}

number of samples used in the study (Anjos et al. 2010, Vielliard et al. 2010). The PAI of each species was calculated for all study area and for each vegetation type separately.
To evaluate if the sampling effort applied was sufficient to sample the most bird species in the local community, we created a collector curve with the observed and estimated bird species richness 
in relation to the sampling effort applied (number of stations or point counts). Bird species richness was estimated using the Jackknife 1 estimator (Magurran 2011).

The differences in avifauna abundance and richness between vegetation types were tested using Analysis of Variance (ANOVA). The community ordination in relation to composition and abundance of species was made using NonMetric Multidimensional Scaling (NMDS) with two dimensions, using Bray-Curtis distance indices. Additionally, we used an Analysis of Similarity (ANOSIM), with the sequential Bonferroni test, to verify the levels of similarity between the bird communities among the different vegetation types.

All analyses used in this study were made in the software Past version 2.17c (Hammer et al. 2001). The taxonomic classification and nomenclature adopted followed the Brazilian Committee of Ornithological Records (CBRO 2014).

\section{RESULTS}

We observed 165 bird species, considering both quantitative and qualitative data (Table SII Supplementary Material). In point counts the observed species richness was 110 bird species. This value corresponded to $66.6 \%$ of the diversity observed in all study area, using quantitative and qualitative data, and $78.4 \%$ of the estimated species richness (Jackknife $1=140.23$ species) in the 40 point counts used (Figure 2).

Considering only quantitative data obtained in point counts, the 11 most abundant species in the study area corresponded to $51 \%$ of total bird abundance, while $49 \%$ of bird abundance was divided between the 99 remaining species, with 21 species being recorded just once. The most abundant species in the study area were Basileuterus culicivorus, Cyanocorax cyanomelas, Hemithraupis guira, Cyanocorax chrysops,

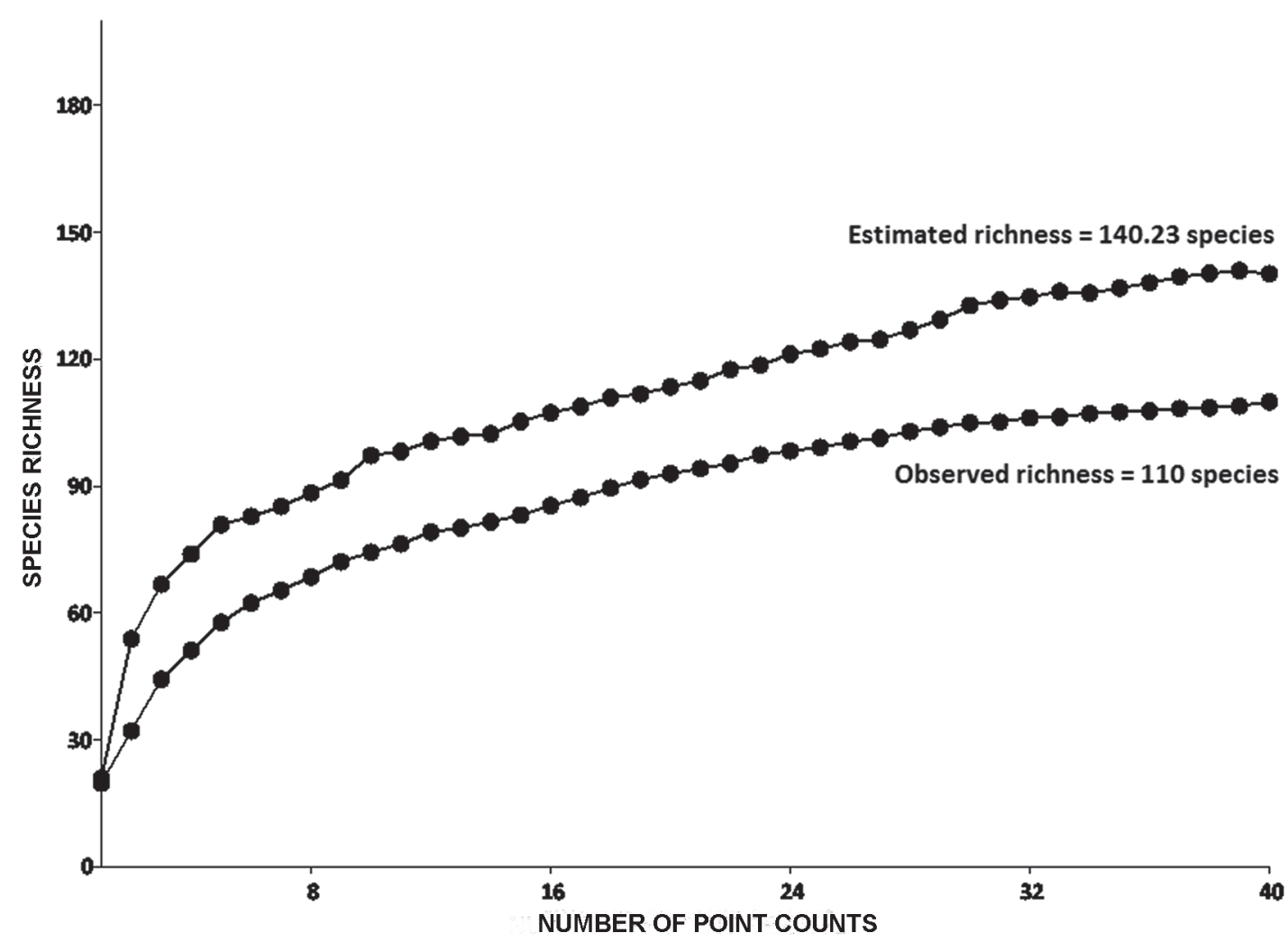

Figure 2 - Collector curve with the observed and estimated bird species richness along the vegetation gradient in Maciço do Urucum, western Brazil. 
Pyrrhura molinae, Brotogeris chiriri, Leptotila verreauxi, Turdus leucomelas, Myiothlypis flaveola, Herpsilochmus atricapillus and Thamnophilus sticturus (Table SII).

Bird abundance and species richness varied among the different vegetation types (Abundance: $\mathrm{F}_{4,35}=11.64, \mathrm{p} \leq 0.0001$; Richness: $\mathrm{F}_{4,35}=18.7, \mathrm{p} \leq$ 0.0001 ) (Figure 3). The bird abundance was higher in riparian forests, submontane forests and forested savannas, with significant statistical differences in relation to altitudinal grasslands $(\mathrm{p} \leq 0.01)$. Riparian forests, submontane forests and forested savannas also have significantly higher bird species richness in relation to altitudinal grasslands ( $\mathrm{p} \leq$ $0.005)$, as well as between forested savannas and arboreal savannas $(\mathrm{p} \leq 0.05)$ (Figure 3 ).

The ordination analysis showed there was a trend in separation of the bird community at Maciço do Urucum between forest formations (riparian forests, submontane forests and forested savannas) and open areas (altitudinal grasslands) (NMDS, Stress: 0.14; $\mathrm{R}^{2}=0.78$ ) (Figure 4). However, the stations of arboreal savannas did not show this trend, with half of these stations located within forest formations, while others formed a different group or were located near altitudinal grasslands stations. The similarity analysis pointed out differences in bird communities between the vegetation types (Anosim, $\mathrm{R}=0.53, \mathrm{p} \leq 0.0001$ ), with significant dissimilarities between all vegetation types, except riparian forests and submontane forests, which have high similarity in their bird communities ( $\mathrm{R}$ $=0.15, \mathrm{p}=0.64)$.

\section{DISCUSSION}

In the study area we recorded 110 species through point counts, which represents $78.4 \%$ of the estimated richness and $66.6 \%$ of richness observed by qualitative methods. These results show that the sampling effort and the point count method were suitable for sampling the majority of local bird species richness.

Most bird species recorded by point counts were considered rare in the study area. The 11 most abundant species, or $10 \%$ of the local richness, represented $51 \%$ of the bird abundance, while $49 \%$ of the bird abundance belonged to the other 99 species, or $90 \%$ of the local richness. This data corroborated the general pattern of bird communities, which are characterized by
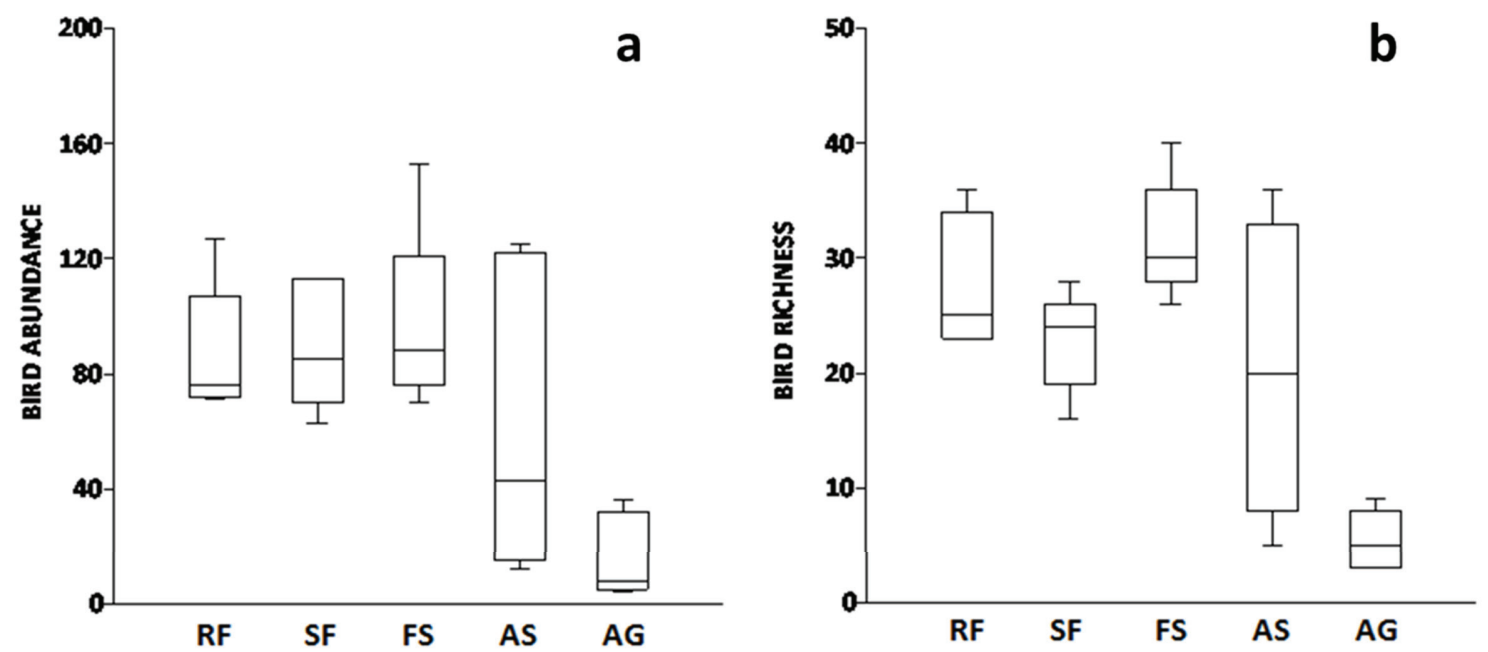

Figure 3 - Differences in bird abundance (a) and species richness (b) between vegetation types which occur in Maciço do Urucum, western Brazil. Legend: RF (Riparian Forests), SF (Submontane Forests), FS (Forested Savannas), AS (Arboreal Savannas), AG (Altitudinal Grasslands). 
Riparian Forests $\Delta$ Submontane Forests $\boldsymbol{\nabla}$ Forested Savannas

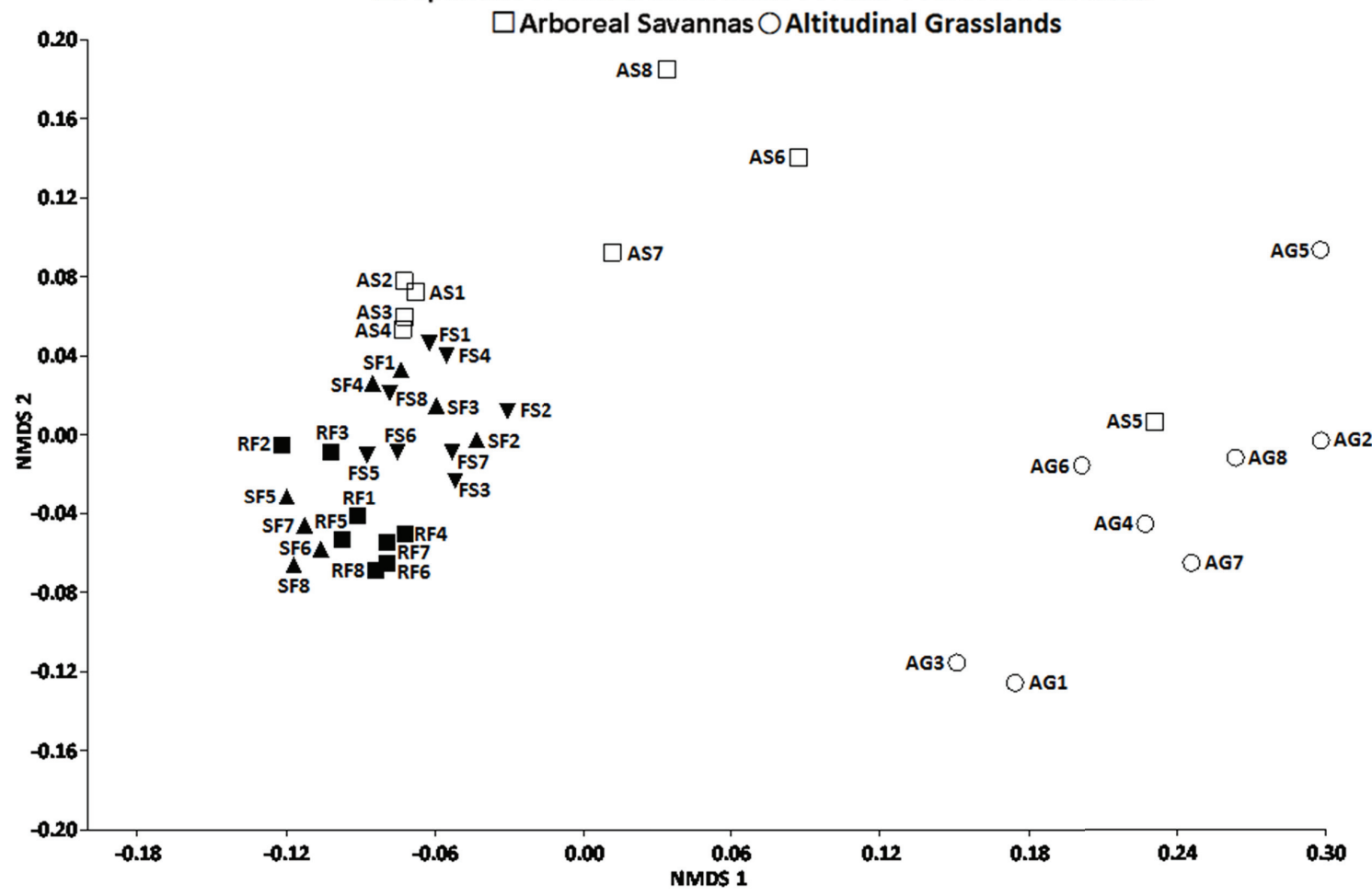

Figure 4 - Non-Metric Multidimensional Scaling (NMDS, Bray-Curtis distance) (Stress $=0.14, \mathrm{R}^{2}=0.78$ ) and Anosim ( $=0.53, \mathrm{p} \leq 0.0001)$ of a bird community in different vegetation types at Maciço do Urucum, western Brazil.

the dominance of a few abundant species, while most bird species are rare (Aleixo and Vielliard 1995, Almeida et al. 1999, Pozza and Pires 2003, Donatelli et al. 2004, 2007, Lyra-Neves et al. 2004, Telles and Dias 2010).

The most abundant species in this study area present wide geographic distributions and are abundant in other regions of western Brazil, such as the Pantanal wetlands (Tubelis and Tomas 1999), Cerrado (Posso et al. 2013), ecotone between Cerrado and Seasonal Forests of High Paraná River Basin (Godoi et al. 2013) and Serra da Bodoquena (Godoi et al. 2016). However, among the locally abundant species, some species present restrict distributions in Brazil, like Pyrrhura molinae and Thamnophilus sticturus, which only occur in the extreme west of the country (Van Perlo 2009), being widely distributed in Chiquitano Forests of Bolivia (Flores et al. 2001, 2002, Brooks et al. 2005) and/ or in the Bolivian and Paraguayan Chaco (Brooks 1997, Ayuso and Sánchez 2002, Zyskowski et al. 2003).

The majority of species with low abundance in this study area is common in other regions of western Brazil (Pivatto et al. 2006, Godoi et al. 2013, Nunes et al. 2013) and are typically found in open areas, which explains their scarcity in the forested Maciço do Urucum. However, among locally rare species, we observed forest birds which are rare in other regions of western Brazil, like Platyrinchus mystaceus, and rare raptors, as Harpia harpyja, Spizaetus ornatus, Buteo platypterus, Micrastur ruficollis and Falco deiroleucus (Pivatto et al. 2006, Godoi et al. 2013, Nunes et al. 2013). Some migratory species were also rare in the study area, including Empidonomus varius, Turdus amaurochalinus, Legatus leucophaius, Coccyzus americanus, Myiarchus swainsonii and Contopus cinereus (Nunes and Tomas 2008), which 
are common in other regions of western Brazil (Pivatto et al. 2006, Godoi et al. 2013, Nunes et al. 2013).

The bird abundance and species richness were higher in forested savannas, riparian forests and submontane forests, when compared to arboreal savannas, and higher in all vegetation types when compared to altitudinal grasslands. These results can be explained by the hypothesis of environmental heterogeneity, which states that environments with more heterogeneous structure have higher diversity than environments with less complex structures (MacArthur and MacArthur 1961, Tews et al. 2004).

The increase in environmental heterogeneity in gradients of grasslands, savannas and forests occurs by the addition of tree and shrub density, as well as other variables related to vegetation structure, as litter abundance, canopy height and canopy cover (Tubelis and Cavalcanti 2000, Skowno and Bond 2003). This increase in environmental heterogeneity provides greater diversity of ecological niches, allowing higher diversification in resource exploitation and consequently greater species diversity (MacArthur and MacArthur 1961, Tews et al. 2004). So, the environments with more heterogeneity, especially those with more vertical stratification, like different forest types, generally have greater species diversity than environments with less vertical heterogeneity, as savannas and grasslands (Tubelis and Cavalcanti 2000, 2001, Figueira et al. 2006, Piratelli and Blake 2006, Godoi et al. 2016), although in some cases arboreal savannas (cerrado stricto sensu) have diversity as great as forests (Posso et al. 2013).

The composition of bird communities in forests and savannas were different from the composition in altitudinal grasslands. The riparian forests and submontane forests presented greater similarity in species composition, most likely due to the similarity in vegetation structure (pers. obs.) and the spatial proximity between these areas, forming a continuum of forests with high forest species diversity.

The forested savannas presented bird communities that are just as similar to riparian forests and submontane forests, as well as to arboreal savannas. So, the forested savannas of Maciço do Urucum shared bird species with local forests and arboreal savannas, which could explain their higher diversity in relation to the other vegetation types studied.

The bird communities in arboreal savannas formed two distinct groups, one consisting of more preserved areas (AS1-AS4), with greater similarity to forested savannas, riparian forests and submontane forests, and the second group consisting of disturbed areas (AS5-AS8), which presented particular bird communities or communities more similar to altitudinal grasslands. These arboreal savannas, which are close to altitudinal grasslands, were disturbed by mining activities, causing the loss and reduction of their tree and shrub layer. Consequently, the bird communities in these areas could lose species and be affected by colonization by bird species of the surrounding altitudinal grasslands, such as Elaenia chiriquensis, Troglodytes musculus, Saltatricula atricollis and Emberizoides herbicola.

In general, the results of this study showed that vegetation gradients in mountains affect the local distribution and abundance of bird species, and consequently the composition and structure of bird communities (Navarro 1992, Blake and Loiselle 2000, Melo-Júnior et al. 2001, Mallet-Rodrigues et al. 2010). In the Serra da Bodoquena, a mountainous region also located in the western Brazil, the bird communities are organized in relation to local vegetation gradients, with communities of forests, savannas and grasslands (Godoi et al. 2016). These results show the importance of habitat diversity to bird communities (Tews et al. 2004) and point out the need to maintain all gradients of forests, savannas and grasslands in mountains, as in the 
Maciço do Urucum, for the long term conservation of their birds.

In relation to conservation, the riparian forests, submontane forests and forested savannas of Maciço do Urucum form an extensive vegetation gradient responsible for the preservation of high forest bird diversity, including groups of species sensitive to forest loss, fragmentation and perturbation, such as understory insectivorous birds (Sekercioglu et al. 2002, Martensen et al. 2008, Stratford and Stouffer 2013, Morante-Filho et al. 2015), forest frugivorous birds (Bregman et al. 2014, MoranteFilho et al. 2015) and forest raptors (Carvalho and Marini 2007).

The main insectivorous birds in riparian forests and submontane forests of Maciço do Urucum were Herpsilochmus atricapillus, Xiphorhynchus guttatus, Dendrocolaptes picumnus, Cantorchilus guarayanus and Lanio penicillatus, while in forested savannas main species were Pyriglena leuconota, Thamnophilus sticturus and Myiothlypis flaveola. The understory insectivorous birds are sensitive to forest loss and fragmentation because they are generally more selective in the habitat use, with small body size and restricted ability to cross open areas and move between forest fragments, making them dependent on large and well connected patches of forests in order to maintain their populations (Martensen et al. 2012).

Frugivorous birds, especially larger species, need a high diversity and abundance of fruits, and because of this they tend to be more common in landscapes with large amounts of natural habitats, with large and well connected fragments (Price et al. 1999, Morante-Filho et al. 2015). Fruit eating birds, as Crypturellus undulatus, Pteroglossus castanotis, Trogon curucui, Turdus leucomelas, Tangara sayaca and Hemithraupis guira were common throughout the forest and savanna gradient of Maciço do Urucum, while others such as Crax fasciolata, Penelope superciliaris and Ramphastos toco were less abundant. Frugivorous birds are im- portant to plant communities since they disperse the seeds of many plants, increasing their reproductive success and helping to maintain and restore natural environments (Levey 1988, Pizo and Galetti 2010).

The forest raptors, especially large species, need large forest patches to maintain extensive territories with high prey abundance (Sick 1997, Carvalho and Marini 2007). So, these birds are generally rare and often threatened. In the gradient of riparian forests and submontane forests of our study area three species were recorded, Harpia harpyja and Spizaetus ornatus, which are near extinction on a global level (IUCN 2015), and Spizaetus melanoleucus. The presence of these species in the Maciço do Urucum indicates that the local forests are still capable of maintaining populations of forest raptors, demonstrating the importance of the preservation of these areas, and showing that the occurrence of these species in the western Brazil depends on the maintenance of continuous natural areas (Godoi et al. 2012).

In altitudinal grasslands of the Maciço do Urucum we observed 16 bird species, four of which were found only in these areas. Within these four species, two are considered nearly threatened for extinction on a global level, Porphyrospiza caerulescens and Falco deiroleucus (IUCN 2015). Falco deiroleucus certainly uses other vegetation types of the Maciço do Urucum, since raptors have extensive territories and in general occur in different types of forests and open areas (Sick 1997). On the other hand, Porphyrospiza caerulescens is strongly associated with natural grasslands, especially to the altitudinal grasslands (Lopes 2012), and for the maintenance of the population of this species the preservation of these areas is extremely important.

The altitudinal grasslands of Maciço do Urucum naturally occur in small patches restricted to mountain tops. Individual patches cannot maintain large populations of Porphyrospiza caerulescens, making it necessary to maintain of many patches of altitudinal grasslands for the conservation of this 
species in the region. Unfortunately, the altitudinal grasslands of Maciço do Urucum have been intensively destroyed by mining activities of iron and aluminum, threatening local populations of Porphyrospiza caerulescens and other animals and plants associated with this unique environment.

Mining activities are not the only threat to bird diversity of the Maciço do Urucum. Cattle expansion and human settlements also have caused the loss and fragmentation of forests, savannas and altitudinal grasslands. Despite these threats, the Parque Natural Municipal de Piraputangas is the only protected area of the Maciço do Urucum, with an area of 1300 ha which does not contain all vegetation gradients present in the region. So, it is necessary to create a large Conservation Unit which can protect the entire vegetation gradients of forests, savannas and altitudinal grasslands present in the Maciço do Urucum. This act will certainly contribute to the conservation of birds and help maintain biodiversity in these important and poorly studied mountains located in the Chiquitano Forest domains of western Brazil.

\section{ACKNOWLEDGMENTS}

We would like to thank GBio for the opportunity to study bird communities in Maciço do Urucum, Hannah Doerrier for the English revision of the text, Danilo Ribeiro, Camila Aoki and an anonymous reviewer for their important contributions to this manuscript.

\section{RESUMO}

Diferentes tipos de vegetação estão distribuídos em montanhas de acordo com a altitude, topografia e solo. A composição e estrutura das comunidades de aves nestas áreas podem mudar com o gradiente de vegetação, com comunidades particulares ocupando cada tipo de habitat. Neste estudo nós apresentamos as mudanças na composição, riqueza de espécies e abundância de aves através de um gradiente de florestas, cerrados e campos de altitude no Maciço do Urucum, uma região montanhosa localizada no domínio das Florestas Secas Chiquitanas no oeste do Brasil. Nós registramos 165 espécies de aves por métodos quantitativos e qualitativos. Savanas florestadas, florestas ripárias e florestas submontanas apresentaram a maior riqueza e abundância de aves, enquanto savanas arborizadas e campos de altitude tiveram valores intermediários e baixos, respectivamente. A composição de espécies foi similar entre florestas ripárias e submontanas, enquanto os outros tipos de vegetação apresentaram comunidades de aves mais dissimilares. Nossos resultados demonstraram diferenças na composição, riqueza e abundância de aves entre os tipos de vegetação presentes no Maciço do Urucum, e apontaram a importante função dos gradientes de vegetação para a conservação das comunidades de aves em montanhas. Adicionalmente, este é o primeiro estudo sobre as comunidades de aves nas Florestas Secas Chiquitanas brasileiras, um importante domínio que ocorre no oeste do Brasil e que tem sido pouco estudado.

Palavras-chave: campos de altitude, comunidades de aves, Florestas Secas Chiquitanas, diversidade de habitats, uso do habitat, montanhas.

\section{REFERENCES}

Aleixo A ANd Vielliard JME. 1995. Composição e dinâmica da avifauna da Mata de Santa Genebra, Campinas, São Paulo, Brasil. Rev Bras Zool 12(3): 493511.

ALMEIDA MEC, Vielliard JME AND DiAs MM. 1999. Composição da avifauna em duas matas ciliares na bacia do rio Jacaré-Pepira, São Paulo, Brasil. Rev Bras Zool 16(4): 1087-1098.

Anjos L, Volpato GH, Mendonça LB, SERAFini PP, LOPES EV, BOÇON R, SILVA ES AND BISHEIMER MV. 2010. Técnicas de levantamento quantitativo de aves em ambiente florestal: uma análise comparativa baseada em dados empíricos. In: Von Matter et al. (Eds), Ornitologia e Conservação: Ciência Aplicada, Técnicas de Pesquisa e Levantamento, Technical Books Editora, Rio de Janeiro, RJ, p. 61-76.

AYUSO JG AND SÁNCHEZ GN. 2002. Caracterización avifaunística del Chaco de Santa Cruz - Bolivia. Rev Bol Ecol 12: 87-109.

BLAKE JG AND LOISELLE BA. 2000. Diversity of birds along an elevational gradient in the Cordillera Central, Costa Rica. Auk 117(3): 663-686.

BREgMAn TP, SEKERCIOGLU CH AND TOBIAS JA. 2014. Global patterns and predictors of bird species responses to 
forest fragmentation: Implications for ecosystem function and conservation. Biol Conserv 169: 372-383.

BROOKS DM. 1997. Avian seasonality at a locality in the Central Paraguayan Chaco. Hornero 14: 193-203.

BROOKS DM, PORZECANSKI AL, WEICKER JJ, HONIG RA, SAAVEDRA AM AND HERRERA M. 2005. A preliminary assessment of avifauna of the Bolivian Chiquitano and Cerrado. Ornitol Neotropic 16: 85-99.

CÁCERES NC, Godoi MN, HANNIBAL H AND FERrEIRA VL. 2011. Effects of altitude and vegetation on small mammal distribution in the Urucum Mountains, western Brazil. J Trop Ecol 27: 279-287.

CARVAlHo CEA AND MARINI MAN. 2007. Distribution patterns of diurnal raptors in open and forested habitats in south-eastern Brazil and the effects of urbanization. Bird Conserv Int 17: 367-380.

CBRO - COMITÊ BRASILEIRO DE REGISTROS ORNITOLÓGICOS. 2014. Lista das aves do Brasil. http://www. cbro.org.br. Accessed on April 14, 2015.

DAVIES SE. 1993. Seasonal status, relative abundance and behavior of the birds of Concepción, Dpto. Santa Cruz, Bolivia. Fieldiana Zool 71: 1-33.

Donatelli RJ, Costa TVV AND FERreira CD. 2004. Dinâmica da avifauna em fragmento de mata na Fazenda Rio Claro, Lençóis Paulista, São Paulo, Brasil. Rev Bras Zool 21: 97-114.

Donatelli RJ, Ferreira CD, DALBeto AC AND POSSO SR. 2007. Análise comparativa da assembléia de aves em dois remanescentes florestais no interior de São Paulo, Brasil. Rev Bras Zool 24(2): 362-375.

FigueIRA JEC, CinTRA R, VIANA LR AND YAMASHITA C. 2006. Spatial and temporal patterns of bird species diversity in the Pantanal of Mato Grosso, Brazil: Implications for conservation. Braz J Biol 66(2A): 393-404.

Flores B, RUMIZ DI AND COX G. 2001. Avifauna del bosque semideciduo Chiquitano (Santa Cruz, Bolivia) antes e después de um aprovechamiento forestal selectivo. Ararajuba 9(1): 21-31.

FLORES B, RUMIZ DI, FREDERICKSEN TS AND FREDERICKSEN NJ. 2002. El uso de claros de aprovechamiento forestal por la avifauna de un bosque semideciduo chiquitano de Santa Cruz, Bolivia. El Hornero 17(2): 61-69.

Godoi MN, Morante-Filho JC, FAxina C, Modena ES, Pivatto MaC, Manço DDG, Bocchese R, TERIBELE R, RosA ALM AND STAVIS VK. 2012. Aves de rapina raras no estado de Mato Grosso do Sul, Brasil. Atual Ornitol 170: 41-47.

Godoi MN, Morante-FilHo JC, MÓdEnA ES, FAXINA C, TIZIANEL FAT, BOCCHESE R, PIVATTO MAC, NUNES AP AND Posso SR. 2013. Birds of Upper Paraná River Basin in the State of Mato Grosso do Sul, Brazil. Rev Bras Ornitol 21(3): 176-204.
Godol MN, SOUZA FL, LAPS RR AND RIBEIRO DB. 2016. Composition and structure of bird communities in vegetational gradients of Bodoquena Mountains, western Brazil. An Acad Bras Cienc 88: 211-225.

HAMMER Ø, HARPER DAT AND RYAN PD. 2001. PAST: Palaeontological statistics software package for education and data analysis. Palaeontol Electronica 4(1): 9.

IUCN. 2015. The IUCN Red List of Threatened Species. Version 2015.1. <www.iucnredlist.org>. Downloaded on June 17, 2015.

JANKOWSKi JE, MERKORD CL, RIOS WF, CABRERA KG, REVILLA NS AND SILMAN MR. 2012. The relantionship of tropical bird communities to tree species composition and vegetation structure along an Andean elevational gradient. J Biogeogr 40: 950-962.

LEVEY DJ. 1988. Spatial and temporal variation in Costa Rican fruit and fruit-eating bird abundance. Ecol Monogr 58: 251-269.

LOPES LE. 2012. Notas sobre a campainha-azul Porphyrospiza caerulescens. Atual Ornitol 167: 57-68.

LYRA-NEVES RM, DiAS MM, AZEVEDO-JÚNIOR SM, TELINO-JÚNIOR WR AND LARRAZÁBAL MEL. 2004. Comunidades de aves da Reserva Estadual de Gurjaú, Pernambuco, Brasil. Rev Bras Zool 21(3): 581-592.

MACARTHUR R AND MACARTHUR J. 1961. On bird species diversity. Ecology 43: 594-598.

MAgurRAN AE. 2011. Medindo a Diversidade Biológica, Editora da Universidade Federal do Paraná (UFPR), Curitiba, PR, $261 \mathrm{p}$.

Mallet-Rodrigues F, PARrini R, Pimentel LMS AND BESSA R. 2010. Altitudinal distribution of birds in a mountainous region in southeastern Brazil. Zoologia 27(4): 503-522.

Martensen AC, Pimentel RG And MetzGer JP. 2008. Relative effects of fragment size and connectivity on bird community in the Atlantic Rain Forest: Implications for conservation. Biol Conserv 141: 2184-2192.

MARTENSEN AC, RiBeiro MC, BANKS-Leite C, PRADO PI AND METZGer JP. 2012. Associations of Forest Cover, Fragment Area, and Connectivity with Neotropical Understory Bird Species Richness and Abundance. Conserv Biol 26: 1100-1111.

MELO-JÚNIOR TA, VASCONCELOS MF, FERNANDES GW AND MARINI MA. 2001. Bird species distribution and conservation in Serra do Cipó, Minas Gerais, Brazil. Bird Conserv Int 11: 189-204.

Morante-Filho JC, FARIA D, MARIANO-NETO E AND RHODES J. 2015. Birds in Anthropogenic Landscapes: The Responses of Ecological Groups to Forest Loss in the Brazilian Atlantic Forest. PLoS ONE 10(6): 1-18.

NAVARRO AGS. 1992. Altitudinal distribution of birds in the Sierra Madre del Sur, Guerrero, Mexico. Condor 94: 2939. 
Nunes AP ET AL. 2013. Aves da Serra de Maracaju, Mato Grosso do Sul, Brasil. Rev Bras Ornitol 21(1): 75-100.

NUNES AP AND TOMAS WM. 2008. Aves migratórias e nômades ocorrentes no Pantanal, EMBRAPA Pantanal, Corumbá, MS, 123 p.

OLSON DM, Dinerstein E, WIKRAMANAYAKE ED, BURGess ND, POWELl GVN, UNDERWOOD EC, D'AMICO JA, ITOUA I, STRAND HE AND MORRISON JC. 2001. Terrestrial ecorregions of the world: a new map of life on earth. Bioscience 51: 933-938.

PARKER TA. 1993. Bird species recorded at eight sites in the Bolivian chaco. In: Parker TA et al. (Eds), The lowland dry forests of Santa Cruz, Bolivia: A global conservation priority, Rapid Assessment Program (RAP) Working Paper, Vol 4, Conservation International, Washington, DC, p. 82-91.

PIRATElli A AND BlAKE JG. 2006. Bird communities of the Southeastern Cerrado region, Brazil. Ornitol Neotrop 17: 213-225.

Pivatto MAC, Manço DDG, Straube FC, URbenFilho A AND Milano M. 2006. Aves do Planalto da Bodoquena, Estado de Mato Grosso do Sul (Brasil). Atual Ornitol 129: 1-26.

Pizo MA AND GALETTI M. 2010. Métodos e perspectivas do estudo da frugivoria e dispersão de sementes por aves. In: Accordi I et al. (Eds), Ornitologia e conservação: ciência aplicada, técnicas de pesquisa e levantamento, Technical Books, Rio de Janeiro, RJ, p. 492-504.

Posso SR, Freitas MN, Bueno FA, Mizobe RS, Morante-Filho JC AND RagusA-Neto J. 2013. Avian composition and distribution in a mosaic of cerrado habitats (RPPN Parque Ecológico João Basso) in Rondonópolis, Mato Grosso, Brazil. Rev Bras Ornitol 21(4): 243-256.

PotT A, OLIVEIRA AKM, DAMASCENO-JUNIOR GA AND SILVA JSV. 2011. Plant diversity of the Pantanal wetland. Braz J Biol 71(1): 265-273.

Pott A, Silva JSV, SAlis SM, PotT VJE And Silva MP. 2000. Vegetação e uso da terra. In: Silva JSV (Ed), Zoneamento ambiental da Borda Oeste do Pantanal: Maciço do Urucum e adjacências, Embrapa Comunicação e Transferência de Tecnologia, Brasília, DF, p. 111-131.

POZZA DD AND PIRES JSR. 2003. Bird communities in two fragments of semideciduous forest in rural São Paulo state. Braz J Biol 63(2): 307-319.

PRICE OF, WOINARSKI JCZ AND ROBINSON D. 1999. Very large area requirements for frugivorous birds in monsoon rainforests of the Northern Territory, Australia. Biol Conserv 91: 169-180.

REMSEN JV AND PARKER TA. 1993. Bird species recorded at four tall dry forest and cerrado localities in southeastern Bolivia. In: Parker TA et al. (Eds), The lowland dry forests of Santa Cruz, Bolivia: A global conservation priority,
Rapid Assessment Program (RAP) Working Paper, Vol 4, Conservation International, Washington, DC, p. 92-99.

SAlis SM, Silva MP, MATTOS PP, Silva JSV, PotT VJ AND POTT A. 2004. Fitossociologia de remanescentes de floresta estacional decidual em Corumbá, Estado do Mato Grosso do Sul, Brasil. Rev Bras Bot 27(4): 671-684.

SeKercioglu CH, Ehrlich PR, DAILy GC, AYGEN D, GOEHRING D AND SANDI RF. 2002. Disappearance of insectivorous birds from tropical forest fragments. Proc Nat Acad Sci USA 99: 263-267.

SICK H. 1997. Ornitologia Brasileira, Editora Nova Fronteira S.A., Rio de Janeiro, RJ, p. 863.

SKOWNO AL AND BOND WJ. 2003. Bird community composition in an actively managed savanna reserve, importance of vegetation structure and vegetation composition. Biodivers Conserv 12: 2279-2294.

STRATFOrd JA AND Stouffer PC. 2013. Microhabitat associations of terrestrial insectivorous birds in Amazonian rainforest and second-growth forests. J Field Ornithol 84: $1-12$.

Telles M AND Dias MM. 2010. Bird communities in two fragments of Cerrado in Itirapina, Brazil. Braz J Biol 70(3): 537-550.

TEWS J, BROSE U, GRIMM V, TIELBORGERL K, WICHMANN MC, SCHWAGer M AND Jeltsch F. 2004. Animal species diversity driven by habitat heterogeneity/diversity: the importance of keystone structures. J Biogeogr 31: 7992.

TOMAS WM, ISHII IH, STRUSSMANN C, NUNES AP, SALIS SM, Campos Z, FERreira VL, Bordignon M, BARRos ATM AND PADILHA DRC. 2010. Borda Oeste do Pantanal e Maciço do Urucum em Corumbá, MS: área prioritária para a conservação da biodiversidade. Simpósio sobre Recursos Naturais e Socioeconômicos do Pantanal. 9 a 12 de novembro.

TUBELIS DP AND CAVALCANTI RB. 2000. A comparison of bird communities in natural and disturbed non-wetland open habitats in the Cerrado's central region, Brazil. Bird Conserv Int 10: 331-350.

Tubelis DP AND CAVAlCanti RB. 2001. Community similarity and abundance of bird species in open habitats of a central Brazilian Cerrado. Ornitol Neotrop 12: 57-73.

TUBELIS DP AND TOMAS WM. 1999. Distribution of birds in a naturally patchy forest environment in the Pantanal wetland, Brazil. Ararajuba 7(2): 81-89.

VAN PERLO B. 2009. A field guide to the birds of Brazil, Oxford University Press, New York, NY, 435 p.

VASCONCELOS MF AND HOFFMANN D. 2006. Os bosques secos chiquitanos também são nossos! Atual Ornitol 130: 10-11.

VIELLIARD JME, ALMEIDA MEC, ANJOS L AND SILVA WR. 2010. Levantamento quantitativo por pontos de escuta e o Índice Pontual de Abundância (IPA). In: Von Matter S et 
al. (Eds), Ornitologia e Conservação: Ciência Aplicada, Técnicas de Pesquisa e Levantamento, Technical Books Editora, Rio de Janeiro, RJ, p. 45-60.

ZYSKOWSKI K, ROBBINS MB, TOWNSEND PETERSON A, Bostwick KS, CLAY RP AND AMARILLA LA. 2003. Avifauna of the Northern Paraguayan Chaco. Ornitol Neotrop 14: 247-262.

\section{SUPPLEMENTARY MATERIAL}

TABLE SII - Composition, abundance (PAI) and distribution of birds along the vegetation gradient in Maciço do Urucum, western Brazil. $n=$ number of stations. *Species without PAI did not occur in point counts, but were observed in the study area. 